\title{
PENGARUH KOMITMEN ORGANISASIONAL DAN JOB INSECURITY TERHADAP TURNOVER INTENTION KARYAWAN
}

\author{
R. Agung Bagus Dwi Cahya Mulia ${ }^{1}$ \\ Wayan Gede Supartha ${ }^{2}$
}

\author{
${ }^{1,2}$ Fakultas Ekonomi dan Bisnis Universitas Udayana (Unud), Bali, Indonesia \\ e-mail: gungbagusdwicahya@yahoo.com
}

\begin{abstract}
ABSTRAK
Faktor utama dalam keberhasilan suatu organisasi adalah Sumber Daya Manusia (SDM), karena SDM tersebut yang mengelola seluruh sumber daya yang dimiliki perusahaanTujuan penelitian ini adalah untuk menganalisis pengaruh komitmen organisasional dan job insecurity terhadap turnover intention. Metode pengumpulan data yang digunakan yaitu kuesioner dan wawancara. Populasi dalam penelitian ini adalah karyawan Puri Dewa Bharata Hotel \& Villas Legian Kuta Bali. Penelitian ini menggunakan sampel jenuh (sensus), dimana menggunakan keseluruhan populasi yaitu 49 orang karyawan tetap dari Puri Dewa Bharata Hotel \& Villas Legian Kuta Bali. Data di analisis menggunakan teknik analisis regresi linier berganda. Hasil penelitian menunjukkan bahwa komitmen organisasional berpengaruh negatif dan signifikan terhadap turnover intention yaitu semakin tinggi komitmen karyawan terhadap perusahaan akan mengurangi keinginan karyawan untuk keluar. Hasil juga menunjukkan bahwa job insecurity berpengaruh positif dan signifikan terhadap turnover intention yaitu semakin tinggi ketidakamanan kerja yang dirasakan karyawan menyebabkan tingginya keinginan berpindah kerja pada karyawan tersebut.
\end{abstract}

Kata kunci : komitmen organisasional, job insecurity, turnover intention

\begin{abstract}
The main factor in the success of an organization. The purpose of this study is to analyze the effect of organizational commitment and job insecurity to turnover intention. Data collection methods used questionnaires and interviews. The population were employees of Puri Dewa Bharata Hotel \& Villas Legian Kuta Bali. This study used a saturated sample (census), which uses the entire population of 49 permanent employees from Puri Dewa Bharata Hotel \& Villas Legian Kuta Bali. Data were analyzed using multiple linear regression analysis technique. The results showed that organizational commitment has a negative and significant effect on turnover intention that the higher commitment of employees to the company will reduce the desire of employees to come out. The results also show that job insecurity has a positive and significant effect on turnover intention that the higher job insecurity perceived by employee causes high willingness to change work to the employee.

Keywords: organizational commitment, job insecurity, turnover intention
\end{abstract}




\section{PENDAHULUAN}

Perkembangan bisnis di bidang pariwisata yang semakin pesat, menuntut para pengusaha untuk dapat berkompetisi dan tetap bertahan dalam persaingan dan perubahan. Untuk mewujudkan hal tersebut diperlukan sumber daya manusia yang berkualitas agar dapat mencapai tujuan perusahaan. Faktor utama dalam keberhasilan suatu organisasi adalah Sumber Daya Manusia (SDM), karena SDM tersebut yang mengelola seluruh sumber daya yang dimiliki oleh perusahaan. Menurut Ardana dkk. (2012:3) sumber daya manusia adalah harta atau aset paling berharga dan paling penting dimiliki oleh suatu organisasi/perusahaan, karena keberhasilan organisasi sangat ditentukan oleh unsur manusia. Oleh karena itu, perusahaan harus memperhatikan dan memelihara para pekerjanya dengan baik agar pekerja yang memiliki kualifikasi yang baik di dalam perusahaan tidak memiliki keinginan untuk pindah bahkan meninggalkan perusahaan (turnover intention).

Keinginan karyawan untuk meninggalkan perusahaan merupakan fenomena yang sering ditemukan pada suatu organisasi. Rendahnya kegairahan bekerja dan ketidak nyamanan di dalam bekerja akan mendorong tenaga-tenaga potensial untuk mengambil langkah keluar dari perusahaan (intention to leave) dan mencari pekerjaan diperusahaan lain yang dapat memenuhi keinginan mereka. Bila pekerjaan itu cocok dengan kemampuan pekerjaan dan kondisi pekerjaan yang nyaman, maka karyawan tersebut akan betah bekerja di dalam perusahaan itu. Tetapi jika kondisi pekerjaan tidak nyaman maka akan terjadi intention to leave yang tinggi Mudiartha dkk. (2001:252). Andini (2006) menyatakan tingkat 
R. Agung Bagus Dwi Cahya Mulia, Pengaruh Komitmen Organisasional dan Job...

turnover yang tinggi akan menimbulkan dampak yang negatif bagi organisasi, hal ini menciptakan ketidak stabilan dan ketidak pastian terhadap kondisi tenaga kerja dan peningkatan biaya sumber daya manusia yakni berupa biaya pelatihan dan rekrutmen.

Menurut Lekatompessy (2003) turnover mengarah pada kenyataan akhir yang dihadapi suatu organisasi, jumlah karyawan yang meninggalkan organisasi pada periode tertentu, sedangkan keinginan karyawan untuk berpindah (turnover intention) mengacu pada evaluasi individu itu sendiri mengenai kelanjutan hubungan dengan organisasi yang belum diwujudkan dalam tindakan pasti untuk meninggalkan organisasi. Tingginya tingkat turnover intention akan menyebabkan tingginya tingkat turnover, hal ini akan menimbulkan dampak buruk bagi organisasi, seperti menciptakan ketidakpastian terhadap kondisi karyawan dan peningkatan biaya sumber daya manusia. Turnover yang tinggi juga akan mengindikasikan organisasi atau perusahaan yang tidak efektif karena kehilangan karyawan yang berpengalaman dan perlu melatih kembali karyawan baru agar bisa bekerja secara efektif diperusahaan yang bersangkutan.

Penyebab lain dari adanya keinginan berpindah karyawan adalah menurunnya tingkat komitmen organisasi dari karyawan. Mayer et al. (1993) menunjukkan bahwa peningkatan komitmen berhubungan dengan peningkatan produktivitas dan turnover yang semakin rendah. Sopiah (2008:155) menyatakan bahwa komitmen organisasional adalah dimensi perilaku penting yang dapat digunakan untuk menilai kecenderungan karyawan untuk bertahan sebagai anggota perusahaan. Komitmen merupakan sikap yang merefleksikan loyalitas 
karyawan pada perusahaan dan proses berkelanjutan di mana karyawan mengekspresikan perhatiannya terhadap perusahaan dan keberhasilan serta kemajuan yang berkelanjutan. Setiap karyawan akan berkeinginan memberikan yang terbaik dan bahkan bersedia untuk bersikap loyal terhadap organisasi, apabila karyawan merasa puas dengan apa yang diterima di perusahaan bersangkutan.

Komitmen organisasional menunjukkan suatu daya dari seseorang dalam mengidentifikasikan keterlibatannya dalam suatu organisasi (Mowday et al., 1982 dalam Vandenberg, 1992). Komitmen organisasional dibangun atas dasar kepercayaan individu atas nilai-nilai organisasi, kerelaan individu dalam membantu mewujudkan tujuan organisasi dan loyalitas untuk tetap menjadi anggota organisasi. Oleh karena itu komitmen organisasional akan menimbulkan rasa ikut memiliki (sense of belonging) baik individu terhadap organisasi.

Faktor penting lainnya selain komitmen organisasional yang dapat mempengaruhi tingginya turnover intention adalah job insecurity. Judge (1993) menyatakan bahwa salah satu penyebab timbulnya keinginan berpindah (turnover intention) pada karyawan adalah pengaruh buruk dari pemikiran disfunctional. Pengaruh tersebut timbul karena terjadi konflik, perasaan tidak senang dan tidak puas terhadap lingkungan kerja yang dapat memicu rasa tidak aman pada pekerjaan (job insecurity).

Menurut Ashford et al. (1989) job insecurity merupakan cerminan derajat kepada karyawan yang merasakan pekerjaan mereka terancam dan merasakan ketidakberdayaan untuk melakukan segalanya tentang itu. Kondisi ini muncul 
R. Agung Bagus Dwi Cahya Mulia, Pengaruh Komitmen Organisasional dan Job...

karena banyaknya pekerjaan dengan status kontrak maupun outsourcing yang cukup marak diterapkan oleh perusahaan. Makin banyaknya pekerjaan dengan durasi waktu sementara atau tidak permanen, menyebabkan semakin banyaknya karyawan yang mengalami job insecurity. Job insecurity memunculkan berbagai dampak negatif, baik dalam aspek psikologis maupun aspek non psikologis. Dampak aspek psikologis yang muncul bisa berupa penurunan kepuasan kerja, penurunan kreativitas, perasaan murung dan bersalah, kekhawatiran bahkan kemarahan. Ada beberapa penelitian mengenai job insecurity terhadap turnover intention. Utami dan Bonussyeani (2009) menjelaskan bahwa terdapat pengaruh positif job insecurity terhadap turnover intention pada staf pengajar di salah satu perguruan swasta di Kota Salatiga.

Puri Dewa Bharata Hotel \& Villas merupakan hotel bintang 3 dengan lokasi yang sangat strategis, dimana hotel ini dekat dengan pusat perbelanjaan, restaurant, caffe, club malam, dan tujuan wisata lainnya. Akan tetapi Puri Dewa Bharata Hotel \& Villas tidak terlepas dari berbagai masalah, terutama masalah tentang keinginan karyawan untuk keluar dari perusahaan. Berdasarkan hasil wawancara dengan human resource development (HRD) Puri Dewa Bharata Hotel \& Villas, ditemukan adanya masalah tentang turnover karyawan. Hal ini dapat di lihat pada Tabel 1. Data tabel 1 menunjukkan bahwa persentase turnover karyawan dari 2013-2016 mengalami tingkat fluktuasi yang cukup tinggi dari tahun 2013 mengalami peningkatan dan melebihi standar yang ditolerir yaitu sebesar $10 \%$ per tahun. Standar tingkat turnover karyawan yang bisa ditolerir pada setiap perusahaan berbeda- beda. Standar turnover karyawan yang normal 
adalah $10 \%$ namun angka tersebut kini dikesankan terlalu kecil mengingat angkatan kerja baru begitu mudah beralih tempat kerja (Ardianto, 2011).

\section{Tabel 1.}

Data Turnover Karyawan Puri Dewa Bharata Hotel \& Villas Tahun 2013-2016

\begin{tabular}{ccccc}
\hline Tahun & $\begin{array}{c}\text { Jumlah } \\
\text { Karyawan } \\
\text { Masuk } \\
\text { (Orang) }\end{array}$ & $\begin{array}{c}\text { Jumlah } \\
\text { Karyawan } \\
\text { Keluar } \\
\text { (Orang) }\end{array}$ & $\begin{array}{c}\text { Jumlah } \\
\text { Karyawan } \\
\text { (Orang) }\end{array}$ & $\begin{array}{c}\text { Persentase } \\
\text { Turnover } \\
(\%)\end{array}$ \\
\hline 2013 & 3 & 6 & 56 & 10,4 \\
2014 & 5 & 7 & 54 & 12,7 \\
2015 & 3 & 7 & 50 & 13,4 \\
2016 & 7 & 8 & 49 & 16,2 \\
\hline Sumber : HRD Puri Dewa Bharata Hotel \& Villas, 2016 & &
\end{tabular}

Alasan memilih Puri Dewa Bharata Hotel \& Villas sebagai objek penelitian, karena berdasarkan wawancara awal yang dilakukan terdapat beberapa keluhan dari karyawan, yaitu terdapat masalah pada komitmen organisasi karyawan, dimana banyak karyawan yang ingin meninggalkan perusahaan karena merasa kurang dihargai oleh perusahaan. Kemudian ada kecenderungan job insecurity karyawan yang tinggi, dimana karyawan merasa tidak mendapatkan kepastian dari perusahaan akan karirnya didalam perusahaan. Selain itu adanya turnover intention yang cukup tinggi, hal ini dapat dilihat ditabel turnover karyawan yang menunjukkan bahwa tingkat keluar masuk karyawan dinilai cukup tinggi, dan menurut karyawan hal ini disebabkan ketidakpastian dari perusahaan akan masa depan karyawan. Berdasarkan latar belakang yang telah diuraikan maka yang menjadi tujuan dari penelitian ini adalah untuk menganalisis pengaruh komitmen organisasional terhadap turnover intention, dan untuk menganalisis pengaruh job insecurity terhadap turnover intention.

Penelitian Grant et al. (2001) menunjukkan bahwa semakin tinggi komitmen organisasional semakin menurun maksud dan tujuan karyawan untuk 
R. Agung Bagus Dwi Cahya Mulia, Pengaruh Komitmen Organisasional dan Job...

meninggalkan organisasi. Ahmed (2003) menyatakan bahwa komitmen organisasional berpengaruh negatif terhadap turnover intention. Sesuai dengan hasil penelitian Khan (2014) bahwa komitmen organisasional yang tinggi akan mengakibatkan menurunnya turnover intention karyawan. Witasari (2009), menyatakan bahwa komitmen organisasional berpengaruh negatif dan signifikan terhadap turnover intention. Dalam penelitiannya disebutkan bahwa terdapat hubungan yang lebih kuat antara komitmen efektif dengan turnover intention. Selanjutnya dalam penelitian Eka (2014) dinyatakan bahwa komitmen organisasional berpengaruh negatif terhadap intensi keluar karyawan yang berarti semakin tinggi rasa peduli terhadap keberlangsungan perusahaan akan mengurangi keinginan karyawan untuk keluar. Dalam penelitianya disebutkan bahwa komitmen normatif secara dominan mempengaruhi intensi keluar karyawan. Dari beberapa penelitian tersebut maka dapat diajukan hipotesis, sebagai berikut :

$\mathrm{H}_{1}$ : Komitmen Organisasional berpengaruh negatif terhadap Turnover Intention. Karyawan yang mengalami tekanan job insecurity memiliki alasan rasional untuk mencari alternatif pekerjaan lain yang dapat mendukung kelanjutan dan memberikan rasa aman bagi karirnya (Irwandi, 2002). Gunalan dan Adnan (2015) menunjukkan bahwa job insecurity memiliki pengaruh positif terhadap turnover intention. Hanafiah (2014) mendapatkan hasil penelitian yang menyatakan bahwa ketidakamanan bekerja memiliki hubungan positif dengan turnover intention. Penelitian Utami (2009) mengungkapkan bahwa semakin tinggi job insecurity akan menyebabkan rendahnya komitmen organisasional, dan kemudian 
menyebabkan tingginya keinginan berpindah kerja. Penelitian Mizar (2008) juga menyatakan bahwa terdapat pengaruh antara job insecurity dengan intensi pindah kerja karyawan, karena job insecurity yang terjadi secara terus menerus akan mempengaruhi kondisi psikologis karyawan. Jika masalah rasa tidak aman dalam bekerja terus menerus dihadapi karyawan, maka akan menstimulasi munculnya keinginan untuk berpindah kerja atau intensi turnover. Dari beberapa penelitian tersebut maka dapat diajukan hipotesis, sebagai berikut.

$\mathrm{H}_{2}$ : Job Insecurity berpengaruh positif terhadap Turnover Intention

Berdasarkan definisi dan kajian teori dari beberapa para ahli yang ada, maka dapat disusun suatu kerangka pemikiran sebagai dasar penentu hipotesis seperti Gambar 1 sebagai berikut.

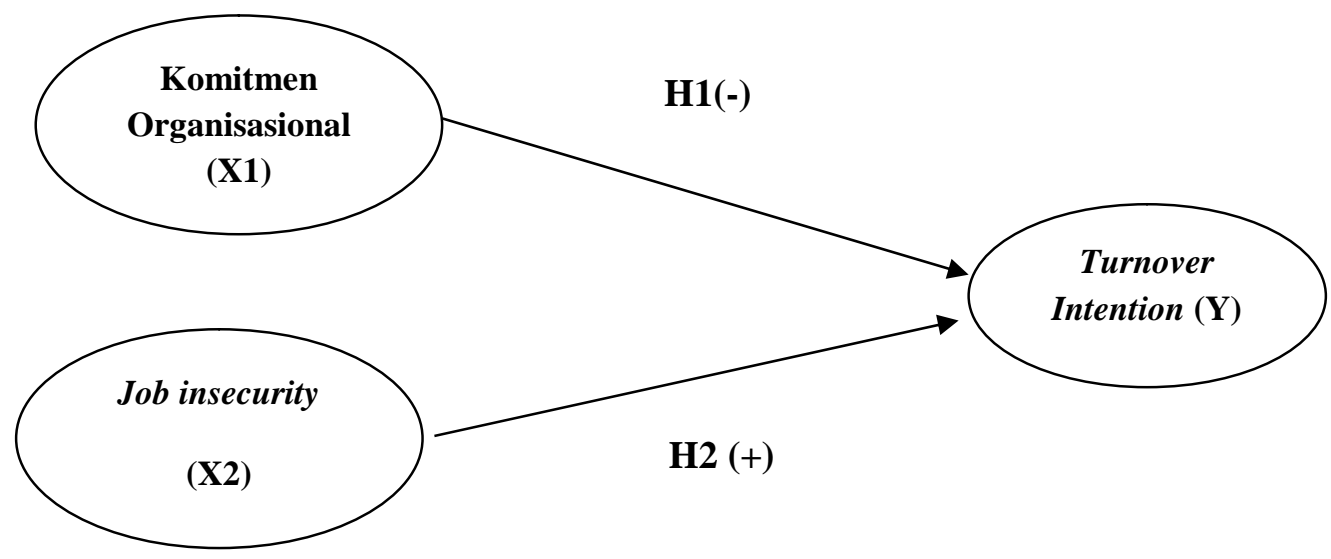

\section{Gambar 1. Model Kerangka Berfikir}

Sumber: Konsep yang dikembangkan dalam penelitian ini, 2017

\section{METODE PENELITIAN}

Pendekatan yang akan digunakan pada penelitian ini adalah pendekatan kuantitatif yang berbentuk asosiatif karena penelitian ini bertujuan untuk 
R. Agung Bagus Dwi Cahya Mulia, Pengaruh Komitmen Organisasional dan Job...

mengetahui hubungan antara dua variabel atau lebih. Penelitian ini berlokasi di Puri Dewa Bharata Hotel \& Villas yang beralamat di Jl. Nakula no.11, Legian, Kuta. Lokasi tersebut dipilih sebagai lokasi penelitian karena belum banyak yang melakukan penelitian di perusahaan tersebut mengenai sumber daya manusianya, ditemukan masalah-masalah yang menyangkut komitmen organisasional dan job insecurity sebagai indikasi-indikasi yang menyebabkan niat karyawan untuk keluar dari perusahaan (turnover intention) di Puri Dewa Bharata Hotel \& Villas.

Objek penelitian ini adalah mengenai komitmen organisasional, job insecurity, dan turnover intention karyawan di Puri Dewa Bharata Hotel \& Villas. Variabel bebas dalam penelitian ini adalah komitmen organisasional $\left(\mathrm{X}_{1}\right)$ dan job insecurity $\left(\mathrm{X}_{2}\right)$, sedangkan variabel terikat dalam penelitian ini adalah turnover intention (Y).

Variabel turnover intention diukur dengan indikator yang digunakan oleh Witasari (2009), yaitu Kecenderungan berfikir untuk meninggalkan organisasi, Keinginan akan mencari pekerjaan pada organisasi lain, Kemungkinan meninggalkan organisasi, Kemungkinan meninggalkan organisasi dalam waktu dekat, dan Kemungkinan meninggalkan organisasi bila ada kesempatan lebih baik.

Variabel komitmen organisasional diukur dengan indikator yang digunakan oleh Zurnali (2010:102) yang terdiri dari dari affective organizational commitment, continuance organizational commitment dan normative organizational commitment. Kemudian indikator yang digunakan untuk mengukur job insecurity (ketidakamanan kerja) yaitu indikator arti pekerjaan itu bagi individu, tingkat ancaman yang dirasakan karyawan mengenai aspek-aspek 
pekerjaan, tingkat ancaman yang kemungkinan terjadi dan mempengaruhi keseluruhan kerja individu, tingkat kepentingan-kepentingan yang dirasakan individu mengenai potensi setiap peristiwa tersebut, tingkat ancaman terhadap pekerjaan pada tahun berikutnya.

Populasi yang digunakan dalam penelitian ini adalah karyawan yang ada di Puri Dewa Bharata Hotel \& Villas Legian Kuta Bali. Menurut Arikunto (2006:112), bila subyeknya besar (lebih dari 100) dapat diambil 10-15 persen atau 20-25 persen atau lebih namun apabila populasi yang diambil kecil (kurang dari 100) semua dapat dijadikan sampel agar mempermudah penelitian. Jumlah karyawan tetap dari Puri Dewa Bharata Hotel \& Villas Legian Kuta Bali adalah 49 orang untuk karyawan tetap, maka metode yang akan digunakan adalah teknik sampel jenuh. Karyawan tetap digunakan karena erat kaitannya dengan variabel Turnover Intention dimana karyawan tetap terikat dengan perusahaan tanpa batasan waktu, sedangkan karyawan kontrak terikat waktu dengan perusahaan sesuai dengan kontrak yang disepakati dengan perusahaan.

Model analisis yang digunakan dalam penelitian ini adalah regresi linier berganda. Permaslahan yang harus dijawab adalah variabel bebas (komitmen organisasional dan job insecurity) berpengaruh secara parsial terhadap variabel terikat (turnover intention). Analisis selanjutnya yang digunakan SPSS 15.0. Model regresi linier berganda sebagai berikut (Utama, 2007:77) :

$\mathrm{Y}=\mathrm{a}+\beta_{1} \mathrm{X}_{1}+\beta_{2} \mathrm{X}_{2}+\mathrm{e}$

Keterangan:

$$
\begin{array}{ll}
\mathrm{Y} & =\text { Turnover Intention } \\
\mathrm{a} & =\text { Konstanta }
\end{array}
$$


R. Agung Bagus Dwi Cahya Mulia, Pengaruh Komitmen Organisasional dan Job...

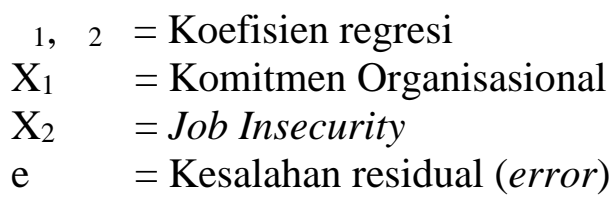

\section{HASIL DAN PEMBAHASAN}

Penelitian ini menggunakan sampel jenuh yang dimana seluruh populasi menjadi sampel, sehingga 49 orang karyawan tetap dari Puri Dewa Bharata Hotel \& Villas Legian Kuta Bali menjadi responden penelitian. Berikut data identitas responden berdasarkan usia, jenis kelamin, dan jenjang pendidikan terakhir reponden. Secara rinci karakteristik responden disajikan pada Tabel 2 sebagai berikut :

Tabel 2.

Karakteristik Responden di Puri Dewa Bharata Hotel \& Villas

\begin{tabular}{|c|c|c|c|c|}
\hline No & Karakteristik & Klasifikasi & $\begin{array}{c}\text { Jumlah } \\
\text { Responden } \\
\text { (orang) }\end{array}$ & $\begin{array}{c}\text { Presentase } \\
\text { Responden } \\
(\%) \\
\end{array}$ \\
\hline \multirow{4}{*}{1} & \multirow{4}{*}{ Usia } & 20 - 29 Tahun & 23 & 46,94 \\
\hline & & 30- 39 Tahun & 14 & 28,57 \\
\hline & & 40 - 49 Tahun & 9 & 18,37 \\
\hline & & $\geq 50$ Tahun & 3 & 6,12 \\
\hline \multicolumn{3}{|c|}{ Jumlah } & 49 & 100 \\
\hline \multirow{2}{*}{2} & \multirow{2}{*}{ Jenis Kelamin } & Laki-Laki & 23 & 46,94 \\
\hline & & Perempuan & 26 & 53,06 \\
\hline \multicolumn{3}{|c|}{ Jumlah } & 49 & 100 \\
\hline \multirow{4}{*}{3} & \multirow{4}{*}{$\begin{array}{c}\text { Jenjang } \\
\text { Pendidikan } \\
\text { Terakhir }\end{array}$} & SMA/SMK/Sederajat & 14 & 28,57 \\
\hline & & Diploma & 9 & 18,37 \\
\hline & & Sarjana & 22 & 44,90 \\
\hline & & Pasca Sarjana & 4 & 8,16 \\
\hline \multicolumn{3}{|c|}{ Jumlah } & 49 & 100 \\
\hline
\end{tabular}

Sumber: Data primer diolah, 2017

Tabel 2 menunjukkan bahwa sebagian besar karyawan di Puri Dewa Bharata

Hotel \& Villas Legian Kuta Bali di dominasi oleh responden yang berusia 20-29 tahun. Rentang usia ini dapat dikategorikan sebagai usia yang produktif dan diasumsikan bahwa Puri Dewa Bharata Hotel \& Villas Legian Kuta Bali sangat membutuhkan karyawan muda agar lebih giat dalam bekerja dan lebih 
bersemangat dalam bekerja. Dengan pegawai yang masih berusia muda juga akan membuat tamu merasa nyaman dilayani karyawan. Data menunjukkan bahwa karyawan Puri Dewa Bharata Hotel \& Villas Legian Kuta Bali di dominasi oleh responden berjenis kelamin perempuan. Hal ini dikarenakan karyawan perempuan memiliki penampilan yang lebih menarik, mampu memberikan layanan dengan baik dan mampu membuat tamu lebih nyaman.

Tabel 2 juga menunjukkan mayoritas karyawan Puri Dewa Bharata Hotel \& Villas Legian Kuta Bali memiliki tingkat pendidikan akhir yaitu Sarjana sebanyak 22 orang atau 44,90 persen. Seseorang yang memiliki tingkat pendidikan Sarjana diasumsikan memiliki pemahaman dan kemampuan yang baik dalam bekerja. Variabel komitmen organisasional dalam penelitian ini merupakan variabel bebas yang diukur dengan menggunakan 9 pernyataan yang berhubungan dengan komitmen organisasional karyawan Puri Dewa Bharata Hotel \& Villas Legian Kuta Bali. Secara rinci hasil penelitian mengenai jawaban responden terhadap variabel komitmen organisasional disajikan pada Tabel 3. Hasil analisis deksriptif sebagaimana disajikan pada tabel 3 menunjukkan skor rata-rata komitmen organisasional sebesar 2,67, yang berarti bahwa karyawan Puri Dewa Bharata Hotel \& Villas Legian Kuta Bali memiliki komitmen yang sedang atau biasa saja terhadap organisasi. Pencapaian nilai rata-rata diikuti oleh adanya indikator yang lebih tinggi dan lebih rendah dari rata-rata variabel komitmen organisasional. Dari 3 indikator yang digunakan untuk mengukur komitmen organisasional, maka terdapat 2 indikator yang nilainya berada di atas nilai rata-rata $(2,67)$ variabel komitmen organisasional yaitu indikator affective organizational commitment, dan 
R. Agung Bagus Dwi Cahya Mulia, Pengaruh Komitmen Organisasional dan Job...

continuance organizational commitment. Indikator continuance organizational commitment memiliki nilai paling tinggi jika dibandingkan dengan indikator lainnya.

Tabel 3.

Deskripsi Jawaban Responden Terhadap Variabel Komitmen Organisasional

\begin{tabular}{|c|c|c|c|c|c|c|c|c|}
\hline \multirow{2}{*}{ No } & \multirow{2}{*}{ Pernyataan } & \multicolumn{5}{|c|}{ Frekuensi Jawaban Responden } & \multirow{2}{*}{$\begin{array}{l}\text { Rata- } \\
\text { Rata }\end{array}$} & \multirow{2}{*}{ Kriteria } \\
\hline & & STS & TS & $\mathbf{N}$ & $\mathbf{S}$ & SS & & \\
\hline 1 & $\begin{array}{l}\text { Saya merasa bangga terhadap } \\
\text { organisasi tempat saya bekerja }\end{array}$ & 6 & 16 & 13 & 13 & 1 & 2,73 & Sedang \\
\hline 2 & $\begin{array}{l}\text { Saya menganggap organisasi } \\
\text { saya saat ini adalah yang terbaik }\end{array}$ & 5 & 17 & 16 & 10 & 1 & 2,69 & Sedang \\
\hline 3 & $\begin{array}{l}\text { Saya terikat secara emosional } \\
\text { pada organisasi tempat saya } \\
\text { bekerja }\end{array}$ & 6 & 10 & 23 & 9 & 1 & 2,78 & Sedang \\
\hline \multicolumn{7}{|c|}{ Rata-rata Indikator Affective organizational commitment } & 2,73 & Sedang \\
\hline 4 & $\begin{array}{l}\text { Saya merasa rugi apabila keluar } \\
\text { dari organisasi tempat saya } \\
\text { bekerja }\end{array}$ & 7 & 11 & 19 & 11 & 1 & 2,76 & Sedang \\
\hline 5 & $\begin{array}{l}\text { Saya menganggap bekerja pada } \\
\text { organisasi saat ini merupakan } \\
\text { suatu kebutuhan }\end{array}$ & 8 & 14 & 15 & 11 & 1 & 2,65 & Sedang \\
\hline 6 & $\begin{array}{l}\text { Saya merasa bahwa bekerja } \\
\text { pada oganisasi ini merupakan } \\
\text { kesempatan yang terbaik }\end{array}$ & 2 & 9 & 22 & 15 & 1 & 3,08 & Sedang \\
\hline \multicolumn{7}{|c|}{ Rata-rata Indikator Continuance organizational commitment } & 2,83 & Sedang \\
\hline 7 & $\begin{array}{l}\text { Saya tidak tertarik pada tawaran } \\
\text { organisasi lain yang mungkin } \\
\text { lebih baik dari tempat saya } \\
\text { bekerja }\end{array}$ & 11 & 19 & 8 & 9 & 2 & 2,43 & Rendah \\
\hline 8 & $\begin{array}{l}\text { Saya berkeinginan untuk } \\
\text { menghabiskan sisa karir pada } \\
\text { organisasi saya saat ini }\end{array}$ & 10 & 17 & 13 & 8 & 1 & 2,45 & Rendah \\
\hline 9 & $\begin{array}{l}\text { Saya menganggap bahwa } \\
\text { loyalitas itu adalah penting }\end{array}$ & 10 & 17 & 12 & 9 & 1 & 2,47 & Rendah \\
\hline \multicolumn{7}{|c|}{ Rata-rata Indikator Normative organizational commitment } & 2,45 & Rendah \\
\hline \multicolumn{7}{|c|}{ Rata-rata keseluruhan variabel komitmen organisasional } & 2,67 & Sedang \\
\hline
\end{tabular}

Sumber : Hasil Olahan Data, 2017

Hal tersebut disebabkan karena karyawan Puri Dewa Bharata Hotel \&

Villas Legian Kuta Bali menganggap bekerja di Puri Dewa Bharata Hotel \&

Villas Legian ini merupakan suatu kebutuhan dan merupakan kesempatan yang

terbaik. Indikator normative organizational commitment sudah memperoleh 
penilaian yang baik dari karyawan berdasarkan hasil kuisioner, namun masih lebih rendah dari nilai rata-rata variabel komitmen organisasional. Dalam upaya meningkatkan komitmen organisasional karyawan ke arah yang lebih baik, maka diharapkan pihak manajemen Puri Dewa Bharata Hotel \& Villas Legian membuat program kerja yang menarik bagi karyawan agar tidak tertarik pada tawaran organisasi lain, kemudian mengadakan sosialisasi dan training bagi karyawan untuk menanamkan pentingnya komitmen pada suatu organisasi. Apabila seorang karyawan sudah memiliki komitmen yang tinggi, tentunya akan tumbuh rasa keinginan untuk menghabiskan sisa karir pada organisasi tersebut dan tumbuh anggapan bahwa loyalitas itu adalah penting pada setiap karyawan.

Tabel 4.

Deskripsi Jawaban Responden Terhadap Variabel Job Insecurity

\begin{tabular}{|c|c|c|c|c|c|c|c|c|}
\hline \multirow{2}{*}{ No } & \multirow{2}{*}{ Pernyataan } & \multicolumn{5}{|c|}{ Frekuensi Jawaban Responden } & \multirow{2}{*}{$\begin{array}{l}\text { Rata- } \\
\text { Rata }\end{array}$} & \multirow{2}{*}{ Kriteria } \\
\hline & & STS & TS & $\mathbf{N}$ & $\mathbf{S}$ & SS & & \\
\hline 1 & $\begin{array}{l}\text { Menurut saya, pekerjaan ini } \\
\text { penting buat saya }\end{array}$ & 0 & 2 & 9 & 33 & 5 & 3,84 & Tinggi \\
\hline 2 & $\begin{array}{l}\text { Saya gelisah terhadap aspek- } \\
\text { aspek pekerjaan seperti } \\
\text { kemungkinan mendapatkan } \\
\text { promosi, mempertahankan } \\
\text { tingkat gaji sekarang atau } \\
\text { memperoleh kenaikan gaji }\end{array}$ & 0 & 2 & 6 & 26 & 14 & 4,04 & Tinggi \\
\hline 3 & $\begin{array}{l}\text { Saya gelisah terhadap } \\
\text { pristiwa-pristiwa yang akan } \\
\text { mempengaruhi kerja saya } \\
\text { seperti dipecat atau } \\
\text { dipindahkan ke unit lain }\end{array}$ & 0 & 0 & 11 & 19 & 19 & 4,16 & Tinggi \\
\hline 4 & $\begin{array}{l}\text { Saya pesimis terhadap masa } \\
\text { depan saya jika tetap bekerja } \\
\text { disini }\end{array}$ & 0 & 2 & 12 & 24 & 11 & 3,90 & Tinggi \\
\hline 5 & $\begin{array}{l}\text { Saya merasa tidak aman } \\
\text { terhadap pekerjaan saya } 1 \\
\text { sampai } 2 \text { tahun yang akan } \\
\text { datang }\end{array}$ & 0 & 2 & 18 & 20 & 9 & 3,73 & Tinggi \\
\hline \multicolumn{7}{|c|}{ Rata-rata keseluruhan variabel job insecurity } & 3,93 & Tinggi \\
\hline
\end{tabular}


R. Agung Bagus Dwi Cahya Mulia, Pengaruh Komitmen Organisasional dan Job...

Variabel job insecurity dalam penelitian ini merupakan variabel bebas yang diukur dengan menggunakan 5 pernyataan yang berhubungan dengan job insecurity karyawan Puri Dewa Bharata Hotel \& Villas Legian Kuta Bali. Secara rinci hasil penelitian mengenai persepsi responden terhadap variabel $J o b$ Insecurity disajikan pada Tabel 4 berikut. Hasil analisis deksriptif sebagaimana disajikan pada tabel 4 menunjukkan skor rata-rata job insecurity sebesar 3,93, yang berarti bahwa sebagian besar karyawan Puri Dewa Bharata Hotel \& Villas Legian Kuta Bali memiliki job insecurity yang tinggi. Pencapaian nilai rata-rata diikuti oleh adanya indikator yang lebih tinggi dan lebih rendah dari rata-rata variabel job insecurity. Dari 5 indikator yang digunakan untuk mengukur job insecurity, maka terdapat 2 indikator yang nilainya berada di atas nilai rata-rata $(3,93)$ variabel job insecurity yaitu indikator tingkat ancaman yang dirasakan karyawan mengenai aspek-aspek pekerjaan dan tingkat ancaman yang kemungkinan terjadi dan mempengaruhi keseluruhan kerja individu. Indikator tingkat ancaman yang kemungkinan terjadi dan mempengaruhi keseluruhan kerja individu memiliki nilai paling tinggi jika dibandingkan dengan indikator lainnya. Hal tersebut disebabkan karena karyawan gelisah terhadap peristiwa-peristiwa yang akan mempengaruhi kerja karyawan seperti dipecat atau dipindahkan ke unit lain karena kondisi Hotel saat ini sedang sepi. Apalagi dengan situasi di Bali yang sedang mengalami erupsi Gunung Agung yang membuat jumlah wisatawan datang ke Bali berkurang, sehingga menyebabkan hampir seluruh hotel yang ada di Bali khususnya Puri Dewa Bharata Hotel \& Villas Legian Kuta mengalami penurunan omset penjualan kamar dan mengurangi jumlah pegawai. 
Guna mengurangi rasa ketidakamanan kerja (job insecurity) yang dirasakan karyawan, maka pihak manajemen sebaiknya memberikan pengertian dan sosialisasi pada suluruh karyawan bahwa peristiwa-peristiwa seperti kondisi hotel sedang sepi tidak akan menyebabkan karyawan dipecat atau dipindahkan ke unit lain. Selain itu, sebaiknya pimpinan perusahaan memberikan semangat ditengah situasi hotel sedang sepi agar karyawan tidak merasa gelisah atau khawatir dipecat. Kondisi hotel yang sepi sebaiknya dimanfaatkan untuk menumbuhkan rasa kekeluargaan diantara seluruh karyawan, dengan mengadakan acara gathering karyawan, sehingga hubungan antar karyawan menjadi lebih akrab. Rasa kekeluargaan yang tercipta tersebut tentunya akan membuat karyawan menjadi lebih baik dalam bekerja dan dapat mengurangi rasa ketidakamanan kerja pada karyawan.

Tabel 5.

Deskripsi Jawaban Responden Terhadap Variabel Turnover Intention

\begin{tabular}{|c|c|c|c|c|c|c|c|c|}
\hline \multirow{2}{*}{ No } & \multirow{2}{*}{ Pernyataan } & \multicolumn{5}{|c|}{ Frekuensi Jawaban Responden } & \multirow{2}{*}{$\begin{array}{l}\text { Rata- } \\
\text { Rata }\end{array}$} & \multirow{2}{*}{ Kriteria } \\
\hline & & STS & TS & $\mathbf{N}$ & $\mathbf{S}$ & SS & & \\
\hline 1 & $\begin{array}{l}\text { Saya sering berfikir untuk } \\
\text { keluar dari perusahaan tempat } \\
\text { saya bekerja }\end{array}$ & 0 & 5 & 7 & 25 & 12 & 3,90 & Tinggi \\
\hline 2 & $\begin{array}{l}\text { Saya merasa kurang cocok } \\
\text { berada di perusahaan ini }\end{array}$ & 0 & 3 & 19 & 16 & 11 & 3,71 & Tinggi \\
\hline 3 & $\begin{array}{l}\text { Saya mempunyai keinginan } \\
\text { untuk keluar dari perusahaan } \\
\text { tempat saya bekerja }\end{array}$ & 0 & 2 & 12 & 25 & 10 & 3,88 & Tinggi \\
\hline 4 & $\begin{array}{l}\text { Saya akan mencari pekerjaan } \\
\text { lain di tahun depan }\end{array}$ & 0 & 2 & 12 & 22 & 13 & 3,94 & Tinggi \\
\hline 5 & $\begin{array}{l}\text { Saya akan mengevaluasi untuk } \\
\text { menemukan pekerjaan yang } \\
\text { layak di tempat lain }\end{array}$ & 0 & 0 & 15 & 26 & 8 & 3,86 & Tinggi \\
\hline \multicolumn{7}{|c|}{ Rata-rata keseluruhan variabel Turnover Intention } & 3,86 & Tinggi \\
\hline
\end{tabular}

Variabel Turnover Intention dalam penelitian ini merupakan variabel terikat yang diukur dengan menggunakan 5 pernyataan yang berhubungan dengan 
R. Agung Bagus Dwi Cahya Mulia, Pengaruh Komitmen Organisasional dan Job...

turnover intention Puri Dewa Bharata Hotel \& Villas Legian Kuta. Secara rinci hasil penelitian mengenai persepsi responden terhadap variabel turnover intention disajikan pada Tabel 5. Tabel 5 menunjukkan secara keseluruhan rata-rata jawaban responden terhadap variabel turnover intention memiliki nilai sebesar 3,86. Hasil penyebaran kuisioner menunjukkan bahwa Karyawan Puri Dewa Bharata Hotel \& Villas Legian Kuta Bali memiliki perilaku turnover intention yang tinggi. Pencapaian nilai rata-rata diikuti oleh adanya indikator yang lebih tinggi dan lebih rendah dari rata-rata variabel turnover intention. Dari 5 indikator yang digunakan untuk mengukur turnover intention, maka terdapat 3 indikator yang nilainya berada di atas nilai rata-rata $(3,86)$ variabel turnover intention yaitu indikator kecenderungan berfikir untuk meninggalkan organisasi, kemungkinan meninggalkan organisasi dan kemungkinan meninggalkan organisasi dalam waktu dekat. Indikator kemungkinan meninggalkan organisasi dalam waktu dekat memiliki nilai paling tinggi jika dibandingkan dengan indikator lainnya. Hal tersebut disebabkan karena karyawan Puri Dewa Bharata Hotel \& Villas Legian Kuta Bali memiliki komitmen yang cukup rendah dan memiliki rasa ketidakamanan kerja seperti rasa khawatir di pecat, sehingga karyawan akan mencari pekerjaan lain di tahun depan.

Indikator mencari pekerjaan lain di tahun depan memperoleh nilai tertinggi dibandingkan indikator lainnya, maka dalam upaya mengurangi tingkat turnover intention karyawan, diharapkan pihak manajemen Puri Dewa Bharata Hotel \& Villas Legian membuat karyawan merasa cocok dan nyaman bekerja di Puri Dewa Bharata Hotel \& Villas Legian dengan cara menciptakan hubungan tenaga kerja 
yang positif baik antara atasan dengan karyawan maupun antara sesama karyawan, agar karyawan merasa nyaman dan cocok dengan lingkungan kerja sehingga dapat mengurangi keinginan karyawan Puri Dewa Bharata Hotel \& Villas Legian untuk mencari pekerjaan lain.

Uji asumsi klasik dalam penelitian ini dilakukan dengan tujuan untuk memastikan hasil yang diperoleh memenuhi asumsi dasar di dalam analisis regresi. Hasil uji asumsi klasik yang dilakukan dalam penelitian ini adalah uji normalitas, uji multikoliniearitas dan uji heteroskedastisitas.

Tabel 6.

Hasil Uji Normalitas

\begin{tabular}{lc}
\hline & Unstandardized Residual \\
\hline $\mathrm{N}$ & 49 \\
Kolmogorov-Smirnov $Z$ & 0,637 \\
Asymp.Sig.(2-tailed) & 0,811 \\
\hline
\end{tabular}

Sumber : Data primer diolah, 2017

Hasil uji normalitas pada Tabel 6 menunjukkan bahwa nilai Kolmogorov Sminarnov (K-S) sebesar 0,637, sedangkan nilai Asymp. Sig. (2-tailed) sebesar 0,811. Hasil tersebut mengindikasikan bahwa model persamaan regresi sudah berdistribusi normal karena nilai Asymp. Sig. (2-tailed) lebih besar dari nilai alpha 0,05 .

Tabel 7. Hasil Uji Multikoleniaritas

\begin{tabular}{cccc}
\hline No & Variabel & Tolerance & VIF \\
\hline 1 & Komitmen Organisasional & 0,766 & 1,305 \\
2 & Job Insecurity & 0,766 & 1,305 \\
\hline
\end{tabular}
Sumber : Data primer diolah, 2017

Hasil uji multikolinieritas pada Tabel 7 menunjukkan bahwa nilai tolerance dan VIF dari variabel Komitmen Organisasional, dan Job Insecurity menunjukkan 
R. Agung Bagus Dwi Cahya Mulia, Pengaruh Komitmen Organisasional dan Job...

nilai tolerance untuk setiap variabel lebih besar dari 10\% dan nilai VIF lebih kecil dari 10 yang berarti model persamaan regresi bebas dari multikolinearitas.

Hasil uji heteroskedastisitas pada Tabel 8 menunjukkan bahwa nilai signifikansi dari variabel komitmen organisasional sebesar 0,678 dan variabel job insecurity sebesar 0,753 . Nilai tersebut lebih besar dari 0,05 yang berarti tidak terdapat pengaruh antara variabel bebas terhadap absolute residual. Dengan demikian, model yang dibuat tidak mengandung gejala heteroskedastisitas.

\section{Tabel 8.}

Hasil Uji Heteroskedastisitas

\begin{tabular}{|c|c|c|c|c|c|}
\hline \multirow[t]{2}{*}{ Variabel } & \multicolumn{2}{|c|}{$\begin{array}{c}\text { Unstandardized } \\
\text { Coefficients }\end{array}$} & \multirow{2}{*}{$\begin{array}{c}\text { Standardized } \\
\text { Coefficients }\end{array}$} & \multirow[t]{2}{*}{$\mathrm{t}$} & \multirow[t]{2}{*}{ Sig. } \\
\hline & $\mathrm{B}$ & Std. Error & & & \\
\hline (Constant) & .448 & 1.447 & & .310 & .758 \\
\hline Komitmen Organisasional & .012 & .028 & .070 & .418 & 678 \\
\hline Job Insecurity & .016 & .051 & .053 & .316 & .753 \\
\hline
\end{tabular}

Pengujian data dalam penelitian ini menggunakan teknik analisis regresi linear berganda untuk menguji hubungan antara 2 atau lebih variabel. Perhitungan koefisien regresi dilakukan dengan analisis regresi melalui software SPSS 22.0 for Windows, diperoleh hasil yang ditunjukan pada Tabel 9 berikut.

\section{Tabel 9.}

Hasil Analisis Regresi Linier Berganda

\begin{tabular}{|c|c|c|c|c|c|}
\hline & \multicolumn{2}{|c|}{$\begin{array}{l}\text { Unstandardized } \\
\text { Coefficients }\end{array}$} & \multirow{2}{*}{$\begin{array}{l}\text { Standardized } \\
\text { Coefficients } \\
\text { Beta }\end{array}$} & \multirow[b]{2}{*}{$\mathrm{t}$} & \multirow[b]{2}{*}{ Sig. } \\
\hline & $\mathrm{B}$ & Std. Error & & & \\
\hline (Constant) & 10.257 & 2.382 & & 4.305 & .000 \\
\hline Komitmen Organisasional & -.157 & .046 & -.296 & -3.428 & .001 \\
\hline Job Insecurity & .651 & .083 & .676 & 7.825 & .000 \\
\hline R Square & & & & & 0,737 \\
\hline Adjusted R Square & & & & & 0,726 \\
\hline F Hitung & & & & & 64,566 \\
\hline Signifikansi F & & & & & 0,000 \\
\hline
\end{tabular}


Berdasarkan hasil analisis regresi seperti yang disajikan pada Tabel 9, maka dapat dibuat persamaan regresi sebagai berikut :

$$
\begin{aligned}
& Y=\alpha-\beta_{1} X_{1}+\beta_{2} X_{2}+e_{1} \\
& Y=10,257-0,157 X_{1}+0,651 X_{2}+e_{1}
\end{aligned}
$$

Nilai koefisien regresi variabel komitmen organisasional bernilai negatif dengan nilai signifikansi uji t kurang dari 0,05 . Hal ini menunjukkan bahwa variabel komitmen organisasional memiliki pengaruh negatif yang signifikan terhadap variabel turnover intention. Nilai koefisien regresi variabel job insecurity bernilai positif dengan nilai signifikansi uji $\mathrm{t}$ kurang dari 0,05 . Hal ini menunjukkan bahwa variabel job insecurity memiliki pengaruh positif yang signifikan terhadap variabel turnover intention. Besarnya pengaruh variabel bebas terhadap variabel terikat yang ditunjukkan oleh nilai determinasi total (R Square) sebesar 0,737 mempunyai arti bahwa sebesar $73,7 \%$ variasi turnover intention dipengaruhi oleh variasi komitmen organisasional dan job insecurity, sedangkan sisanya sebesar $26,3 \%$ dijelaskan oleh faktor lain yang tidak dimasukkan ke dalam model.

Hasil analisis pertama menunjukkan bahwa komitmen organisasional berpengaruh negatif dan signifikan terhadap turnover intention. Hal ini memiliki makna bahwa semakin tinggi komitmen organisasional yang dimiliki karyawan Puri Dewa Bharata Hotel \& Villas Legian Kuta Bali, maka akan semakin rendah Turnover Intention yang dilakukan karyawan Puri Dewa Bharata Hotel \& Villas Legian Kuta Bali. Begitu pula sebaliknya, semakin rendah komitmen organisasional yang dimiliki karyawan Puri Dewa Bharata Hotel \& Villas Legian 
R. Agung Bagus Dwi Cahya Mulia, Pengaruh Komitmen Organisasional dan Job...

Kuta Bali, maka akan semakin tinggi turnover intention yang dilakukan karyawan tersebut.

Hasil tersebut mengindikasikan bahwa nilai - nilai yang terkandung dalam komitmen organisasional mampu berdampak nyata terhadap turnover intention karyawan Puri Dewa Bharata Hotel \& Villas Legian Kuta Bali. Komitmen Organisasional yang diukur berdasarkan indikator: affective organizational commitment, continuance organizational commitment dan normative organizational commitment mampu mempengaruhi Turnover Intention karyawan Puri Dewa Bharata Hotel \& Villas Legian Kuta Bali. Temuan ini dapat diartikan bahwa apabila Komitmen Organisasional seluruh karyawan Puri Dewa Bharata Hotel \& Villas Legian Kuta Bali ditingkatkan, maka akan mampu memberikan kontribusi yang signifikan terhadap turnover intention yang dilakukan karyawan.

Penelitian ini mendukung beberapa hasil penelitian sebelumnya dan konsisten dengan hasil penelitian Grant et al. (2001) yang menunjukkan bahwa semakin tinggi komitmen organisasional diharapkan akan dapat menurunkan maksud dan tujuan karyawan untuk meninggalkan organisasi. Penelitian serupa yang dilakukan Ahmed (2003), Khan (2014), Witasari (2009), dan Eka (2014) juga menemukan hasil bahwa komitmen organisasional berpengaruh negatif terhadap intensi keluar karyawan yang berarti semakin tinggi rasa peduli terhadap keberlangsungan perusahaan akan mengurangi keinginan karyawan untuk keluar.

Hasil analisis kedua menunjukkan bahwa job insecurity berpengaruh positif dan signifikan terhadap turnover intention. Hal ini memiliki makna bahwa semakin tinggi Job Insecurity yang dirasakan karyawan Puri Dewa Bharata Hotel 
\& Villas Legian Kuta Bali, maka semakin tinggi pula turnover intention yang akan terbentuk pada karyawan tersebut. Begitu pula sebaliknya, semakin rendah job insecurity yang dirasakan karyawan Puri Dewa Bharata Hotel \& Villas Legian Kuta Bali, maka semakin rendah pula turnover intention yang akan terbentuk pada karyawan Puri Dewa Bharata Hotel \& Villas Legian Kuta Bali.

Hasil tersebut mengindikasikan bahwa nilai - nilai yang terkandung dalam job insecurity mampu dipersepsikan dengan baik dan berdampak nyata terhadap turnover intention pada karyawan Puri Dewa Bharata Hotel \& Villas Legian Kuta Bali. Job Insecurity yang diukur berdasarkan indikator: arti pekerjaan itu bagi individu, tingkat ancaman yang dirasakan karyawan mengenai aspek-aspek pekerjaan, tingkat ancaman yang kemungkinan terjadi dan mempengaruhi keseluruhan kerja individu, tingkat kepentingan-kepentingan yang dirasakan individu mengenai potensi setiap peristiwa tersebut, dan tingkat ancaman terhadap pekerjaan pada tahun berikutnya terbukti mampu meningkatkan turnover intention karyawan Puri Dewa Bharata Hotel \& Villas Legian Kuta Bali. Temuan ini dapat diartikan bahwa apabila rasa ketidakamanan kerja yang dirasakan karyawan dapat dikurangi, maka akan mampu memberikan kontribusi yang signifikan terhadap berkurangnya keinginan karyawan untuk keluar.

Penelitian ini mendukung beberapa hasil penelitian sebelumnya dan konsisten dengan hasil penelitian Irwandi (2002) yang menemukan hasil bahwa job insecurity berpengaruh positif dan signifikan terhadap turnover intention karyawan. Hasil penelitian menjelaskan bahwa karyawan yang mengalami tekanan job insecurity memiliki alasan rasional untuk mencari alternatif pekerjaan 
R. Agung Bagus Dwi Cahya Mulia, Pengaruh Komitmen Organisasional dan Job...

lain yang dapat mendukung kelanjutan dan memberikan rasa aman bagi karirnya. Penelitian serupa yang dilakukan Gunalan dan Adnan (2015), Hanafiah (2014), Utami (2009), dan Mizar (2008) juga memperoleh hasil bahwa Job Insecurity berpengaruh positif dan signifikan terhadap turnover intention. Hal tersebut berarti jika masalah rasa tidak aman dalam bekerja terus menerus dihadapi karyawan, maka akan mendorong timbulnya sikap keinginan untuk berpindah kerja atau turnover intention.

\section{SIMPULAN DAN SARAN}

Simpulan yang dapat diambil berdasarkan hasil analisis dan pembahasan yaitu pertama, komitmen organisasional berpengaruh negatif dan signfikan terhadap turnover intention karyawan Puri Dewa Bharata Hotel \& Villas Legian Kuta Bali. Hal ini menunjukan bahwa semakin tinggi komitmen karyawan Puri Dewa Bharata Hotel \& Villas Legian Kuta Bali maka akan mengurangi keinginan karyawan keluar dari Puri Dewa Bharata Hotel \& Villas Legian Kuta Bali. Kedua, Job insecurity berpengaruh positif dan signifikan terhadap turnover intention karyawan Puri Dewa Bharata Hotel \& Villas Legian Kuta Bali. Hal ini menunjukkan bahwa semakin tinggi rasa ketidakamanan kerja yang dirasakan karyawan Puri Dewa Bharata Hotel \& Villas Legian Kuta Bali, maka semakin meningkatkan rasa keinginan karyawan untuk keluar dari Puri Dewa Bharata Hotel \& Villas Legian Kuta Bali.

Berdasarkan hasil analisis penelitian, pembahasan dan kesimpulan terdapat beberapa saran yang dapat dipergunakan sebagai bahan pertimbangan dalam menentukan kebijakan terkait turnover intention karyawan Puri Dewa Bharata 
Hotel \& Villas Legian Kuta Bali dimasa mendatang, yaitu dalam upaya meningkatkan komitmen organisasional karyawan ke arah yang lebih baik, maka diharapkan pihak manajemen Puri Dewa Bharata Hotel \& Villas Legian membuat program kerja yang menarik bagi karyawan agar tidak tertarik pada tawaran organisasi lain, kemudian mengadakan sosialisasi dan training bagi karyawan untuk menanamkan pentingnya komitmen pada suatu organisasi. Apabila seorang karyawan sudah memiliki komitmen yang tinggi, tentunya akan tumbuh rasa keinginan untuk menghabiskan sisa karir pada organisasi tersebut dan tumbuh anggapan bahwa loyalitas itu adalah penting pada setiap karyawan.

Indikator tingkat ancaman yang kemungkinan terjadi dapat mempengaruhi keseluruhan kerja individu memiliki nilai paling tinggi jika dibandingkan dengan indikator lainnya, maka dalam upaya mengurangi rasa ketidakamanan kerja (job insecurity) yang dirasakan karyawan, pihak manajemen sebaiknya memberikan pengertian dan sosialisasi pada suluruh karyawan bahwa pristiwa-pristiwa seperti kondisi hotel sedang sepi tidak akan menyebabkan karyawan dipecat atau dipindahkan ke unit lain. Selain itu, sebaiknya pimpinan perusahaan memberikan semangat ditengah situasi hotel sedang sepi agar karyawan tidak merasa gelisah atau khawatir dipecat. Kondisi hotel yang sepi sebaiknya dimanfaatkan untuk menumbuhkan rasa kekeluargaan diantara seluruh karyawan, dengan mengadakan acara gathering karyawan, sehingga hubungan antar karyawan menjadi lebih akrab. Rasa kekeluargaan yang tercipta tersebut tentunya akan membuat karyawan menjadi lebih baik dalam bekerja dan dapat mengurangi rasa ketidakamanan kerja pada karyawan. 
R. Agung Bagus Dwi Cahya Mulia, Pengaruh Komitmen Organisasional dan Job...

Indikator mencari pekerjaan lain di tahun depan memperoleh nilai tertinggi dibandingkan indikator lainnya, maka dalam upaya mengurangi tingkat turnover intention karyawan, diharapkan pihak manajemen Puri Dewa Bharata Hotel \& Villas Legian membuat karyawan merasa cocok dan nyaman bekerja di Puri Dewa Bharata Hotel \& Villas Legian dengan cara menciptakan hubungan tenaga kerja yang positif baik antara atasan dengan karyawan maupun antara sesama karyawan, agar karyawan merasa nyaman dan cocok dengan lingkungan kerja sehingga dapat mengurangi keinginan karyawan Puri Dewa Bharata Hotel \& Villas Legian untuk mencari pekerjaan lain.

\section{REFERENSI}

Adnan, Muhammad Akhyar dan Eha Kurniasih. 2000. Analisis Tingkat Kesehatan Perusahaan untuk Memprediksi Potensi Kebankrutan dengan Pendekatan Altman (Kasus pada Sepuluh Perusahaan di Indonesia).Vol. 4 No. 2.

Allen, N.J. dan J.P. Meyer. 1991. The Measurement and Antecedents of Affective, Continuance and Normative Commitment to the Organizational. Journal of Occupational Psychology. 63 (1): 1- 18.

Andini, Rita. 2006. Analisis Pengaruh Kepuasan Gaji, Kepuasan Kerja, Komitmen Organisasional pada Turnover Intention (Studi Kasus pada Rumah Sakit Roemani Muhammadiyah Semarang). Tesis. Program Pasca Sarjana Universitas Diponegoro Semarang

Ardana, Komang. Ni Wayan Mujiati dan I Wayan Mudiartha Utama, 2012. Manajemen Sumber Daya Manusia. Edisi I. Yogyakarta. Graha Ilmu.

Ardianto, Elvinaro. 2011. Metodologi Penelitian untuk Public Relations Kuantitatif dan Kualitatif. Bandung: Simbiosa Rekatama Media.

Arikunto., 2006. Prosedur Penelitian Suatu Pendekatan Praktik. Jakarta: Rineka Aksara.

Eka, Agus Putu. 2014. "Peran Mediasi Komitmen Organisasional pada Pengaruh Stress Kerja dan Kepuasan Kerja terhadap Intensi Keluar Karyawan pada 
Bali Dynasty Resort". Tesis: Program Studi Magister Manajemen, Program Pascasarjana Universitas Udayana Denpasar.

Hanafiah, Agung Wahyu. 2012. Pengaruh Kepuasan Kerja Gaji dan Komitmen Organisasi Terhadap Intensi Turnover. Jurnal Riset Manajemen Sains Indonesia. 3(1). pp: 12-24.

Irwandi Sony, Agus. 2002, "Analisis Pengaruh Job Insecurity terhadap Turnover Intentions : Studi Empiris Pada Akuntan Pendidik di Perguruan Tinggi”. Tesis. Program Studi Magister Sains Akuntansi Universitas Diponegoro.

Judge, T. A. 1993, "Does Affective Dispotition Moderate the Relationship Between Job Satisfaction and Voluntary Turnover?", Journal of Applied Psychology, 78, 395-401.

Khan, Akhter, M., Ali, L., and Hassan, Z., 2013. Association of Human Papilloma Virus Infection and Oral Squamous Cell Carcinoma in Bangladesh. Journal Health Popul Nutr, vol. 31(1), page 65-69.

Kumar, V., Cotran, R.S. and Robbins, S.L., 2007. Buku ajar patologi. 7 edisi , Vol. 1. Jakarta : Penerbit Buku Kedokteran E GC : 189-1.

Kurniasari, L. 2004. Pengaruh Komitmen Organisasi \& Job Insecurity Karyawan Terhadap Intensi Turnover. Tesis. Program Pasca Sarjana Pengembangan Sumber Daya Manusia, Universitas Airlangga Surabaya.

Lekatompessy, J.E. 2003. Hubungan Profesionalisme dengan konsekuensinya: Komitmen Organisasional, Kepuasan Kerja, Prestasi Kerja dan Keinginan Berpindah (Studi Empiris di Lingkungan Akuntan Publik). Jurnal Bisnis dan Akuntansi, Vol.5, No.1, April, hlm.69-84.

Mayer, John P. \& Allen, Natalie J. 1991. A Three-Component Conceptualization of Organisasional Commitment. Human Resource Management Review. 1(1), pp:61-89

Mizar, Yuniar, 2008. Pengaruh Faktor Ketidakamanan Kerja (Job Insecurity) dan Kepuasan Kerja Terhadap Niat Pindah (Turnover Itention) Dengan Komitmen Organisasional Sebagai Variabel Intervening. Semarang: Tesis. Magister Manajemen Universitas Diponegoro.

Mudiartha Utama, I Wayan. 2001. Manajemen Sumber Daya Manusia. Denpasar UPT. Penerbit : Universitas Udayana.

Sopiah. 2008. Prilaku Keorganisasian. Malang: Penerbit ANDI 
R. Agung Bagus Dwi Cahya Mulia, Pengaruh Komitmen Organisasional dan Job...

Sutanto, E.M. 1999. The relationship between employee commitment and job performance. Jurnal Manajemen dan Kewirausahaan, 1 (1), 47 - 55

Utama, Made Suyana. 2007. Buku Ajaran Aplikasi Analisis Kuantitatif. Denpasar: Sastra Utama.

Utama, Made Suyana. 2009. Aplikasi Analisis Kuantitatif. Denpasar: Fakultas Ekonomi Universitas Udayana.

Utami, Intiyas.,Nur Endah Sumiwi Bonussyeani. 2009. Pengaruh Job Insecurity, Kepuasan Kerja, Dan Komitmen Organisasional Terhadap Keinginan Berpindah Kerja. Salatiga: Universitas Kristen Satya Wacana. Jurnal Akuntansi dan Kuangan Indonesia. Vol.6, No.1, pp.117-139

Vandenberg, R.J., \& Lance, C.E. 1992. Examining the Causal Order of Job Satisfaction and Organizational Commitment. Journal of Management. 18(3) ,pp: 153-167.

Vandenberghe, C and Tremblay, M. 2008. The Role of Pay Satifaction and Organizational Commitment in Turnover Intention: A Two-Sample Study. Journal Bus Psychology, 22(1), pp: 275-286

Witasari, L. 2009. Analisis Pengaruh Kepuasan Kerja dan Komitmen Organisasional terhadap Intention to quit (studi empiris pada Novotel Semarang). Thesis, Universitas Diponogoro, Semarang.

Zurnali, Cut 2010. Learning Organization, Competency, Organizational, Commitment dan Customer Orientation: Knowledge Worker-Kerangka Riset MSDM di Masa Depan. Bandung: Unpad Press 